\title{
HFE MUTATIONS AND IRON OVERLOAD IN PATIENTS WITH ALCOHOLIC LIVER DISEASE
}

\author{
Luís COSTA-MATOS ${ }^{1,2}$, Paulo BATISTA², Nuno MONTEIRO², \\ Pedro HENRIQUES ${ }^{2}$, Fernando GIRÃO² and Armando CARVALHO ${ }^{1}$
}

\begin{abstract}
Context - Alcoholic liver disease (ALD) is generally associated with iron overload, which may contribute to its pathogenesis, through increased oxidative stress and cellular damage. There are conflicting reports in literature about hemochromatosis (HFE) gene mutations and the severity of liver disease in alcoholic patients. Objectives - To compare the prevalence of mutations in the hemochromatosis (HFE) gene between patients with ALD and healthy controls; to assess the relation of $H F E$ mutations with liver iron stores and liver disease severity. Methods - Liver biopsy specimens were obtained from 63 ALD patients (during routine treatment) and 52 healthy controls (during elective cholecystectomy). All individuals underwent routine liver function tests and HFE genotyping (to detect wild-type sequences and C282Y, H63D, S65C, E168Q, E168X, V59M, H63H, P160delC, Q127H, Q283P, V53M and W164X mutations). Associations between HFE mutations and risk of excessive liver iron stores, abnormal serum ferritin, liver fibrosis, or necroinflammatory activity were assessed by multivariate logistic regression analysis. Results - ALD patients had significantly higher serum ferritin and transferrin saturation than controls (both $P<0.05$ ), but the distribution of $H F E$ mutations was similar between the two groups. For ALD patients, the odds ratio for having at least one HFE mutation and excessive liver iron stores was 17.23 (95\% confidence interval (CI): 2.09-142.34, $P=0.008)$. However, the presence of at least one HFE mutation was not associated with an increased risk of liver fibrosis or necroinflammatory activity. Active alcohol ingestion showed the strongest association to increased serum ferritin ( $\mathrm{OR}=8.87,95 \% \mathrm{CI}: 2.11-34.78, P=0.003)$. Conclusions $-\mathrm{ALD}$ patients do not present with a differential profile of $H F E$ mutations from healthy controls. In ALD patients, however, the presence of at least one HFE mutation increases the risk of having excessive liver iron stores but has no detectable effects on liver disease activity or severity.
\end{abstract}

HEADINGS - Alcoholic liver disease. Membrane proteins. Iron. Hemochromatosis.

\section{INTRODUCTION}

The relation between liver iron stores and alcoholic liver disease (ALD) is well established. In 1964, hemochromatosis was thought to be a peculiar manifestation of alcoholic cirrhosis ${ }^{(10,11)}$. Despite hemochromatosis being a different disease, up to $33 \%$ of ALD patients ${ }^{(8)}$ and more than half of ALD patients with advanced cirrhosis present with excessive liver iron stores ${ }^{(27)}$. Even so, iron stores never reach the same intensity in ALD as they do in hereditary hemochromatosis ${ }^{(20,32)}$.

Excessive liver iron content has been characterized as an independent risk factor for fibrosis, while in alcoholic cirrhosis the accumulated liver iron concentrations correlate inversely with patient survival ${ }^{(13)}$. It is known that serum iron and ferritin increase linearly with daily alcohol consumption ${ }^{(34)}$. Moreover, serum ferritin levels are higher in ALD patients than in non-alcoholic patients with other chronic liver diseases, such as autoimmune disorders or chronic hepatitis
$\mathrm{C}$ virus (HCV) infection. Interestingly, upon alcohol withdrawal, the increased serum ferritin levels have been shown to rapidly decrease ${ }^{(2,24)}$.

Alcohol consumption has been implicated as the main cause of increased serum ferritin levels in the general population ${ }^{(17,24)}$. The apparent sensitivity of this pathological process was further indicated by a study showing that even moderate alcohol ingestion can affect iron metabolism ${ }^{(18)}$.

In 1996 , a $\mathrm{G} \rightarrow \mathrm{A}$ transition at nucleotide 845 in the HLA-H gene was found to be present as a homozygous mutation in $80 \%$ of hereditary hemochromatosis patients ${ }^{(7)}$. According to this disease association, the gene and its encoded protein were renamed as hemochromatosis (HFE) gene and HFE protein. Since then, studies have determined that the C282Y mutation in $H F E$ is very common in Caucasians. Its allelic frequency averages $6.2 \%$, and it is estimated that $0.4 \%(1 / 260)$ of Europeans are homozygous for $H F E$ C282Y. The mutation itself has become the diagnostic marker of hereditary hemochromatosis ${ }^{(6,16)}$.

Conflicts of interest: The authors declare they have no conflicts of interest related to the publication of this study.

Supportive foundations: Tondela-Viseu Hospital Centre E.P.E., Portugal.

${ }^{1}$ Faculty of Medicine of the University of Coimbra, 3004-504 Coimbra, Portugal; ${ }^{2}$ Tondela-Viseu Hospital Centre E.P.E., $3504-509$ Viseu, Portugal.

Correspondence: Dr. Luís Costa Matos - Serviço de Medicina Interna I, Centro Hospitalar Tondela-Viseu E.P.E. - 3504-509, Portugal. E-mail: costamatos.luis@gmail.com 
Several other HFE mutations have been identified and characterized, including those with very high allelic frequency (H63D: 14\%) and others with very low allelic frequency (S65C: 0.5\%). Interpreting the presence of these mutations, however, requires some caution. Homozygous carriers of $\mathrm{H} 63 \mathrm{D}$ have been found to not be at risk for iron overload. The S65C allele appears to exert its influence only when inherited with homozygous $\mathrm{C} 282 \mathrm{Y}$, wherein it worsens the iron overload ${ }^{(1,16)}$. In contrast, compound heterozygous $\mathrm{C} 282 \mathrm{Y} / \mathrm{H} 63 \mathrm{D}$ or H63D homozygosity may produce only slight increases in serum ferritin and transferrin saturation levels. However, in patients presenting with overt iron overload of unknown cause, it is necessary to investigate both the presence of $H F E$ mutations and other non-genetic causes ${ }^{(4,22)}$.

Hereditary hemochromatosis is considered a functional paradigm of the synergy between alcohol and iron. Under conditions of excessive alcohol ingestion, the phenotypical expression of iron overload increases ${ }^{(31)}$. Patients with hemochromatosis who ingest more than $60 \mathrm{~g}$ of alcohol daily have been characterized as having a 9-fold increased risk of developing cirrhosis ${ }^{(9)}$. In addition, some studies have suggested that HFE mutations may play a role in ALD severity, but other studies have not confirmed these results. The current study was designed to compare the prevalence of HFE mutations between ALD patients and a healthy control population and assess their relations with excessive liver iron stores and liver disease severity (fibrosis grade and necroinflammatory activity).

\section{METHODS}

\section{Participants}

The study design conformed to the ethical guidelines of the 1975 Declaration of Helsinki and was approved by the local Ethics Committees of the University of Coimbra and the Tondela-Viseu Hospital Centre, Portugal.

Patients were recruited from the Liver Diseases Outpatient Consultation Clinic at Tondela-Viseu Hospital Centre. Study enrolment was based on the following inclusion criteria: ALD diagnosis; recent liver biopsy for disease grading and staging, doubts about diagnosis, or the presence of concurrent liver disease. Patients were refused enrolment according to the following exclusion criteria: gastrointestinal bleeding; blood transfusion within the previous 3 months; other relevant liver or systemic diseases; and refusal to provide informed written consent. Of the 69 patients who fulfilled the criteria, 2 were subsequently excluded for lack of sufficient liver tissue and 4 for other liver or systemic diseases that were identified during the follow-up exams.

Healthy controls were recruited from the patient population that was admitted for elective cholecystectomy due to non-complicated gallstones, during which a small liver sample had been obtained during surgery for another study. The inclusion criteria for healthy controls were: alcohol consumption $<20 \mathrm{~g} /$ day in women and $<40 \mathrm{~g} /$ day in men; level of serum ferritin above the lower limit of normal (LLN); and levels of alanine aminotransferase (ALT), aspartate aminotransferase (AST), g-glutamyl transpeptidase (GGT), and alkaline phosphatase (ALP) lower than 3 times the ULN. Patients were excluded according to: anemia; other relevant liver or systemic diseases; of evidence of inflammation, defined as $\mathrm{C}$ reactive protein $(\mathrm{CRP})>2.5 \mathrm{mg} / \mathrm{dL}$; and refusal to provide informed written consent. Finally, 52 controls were enrolled in the study.

\section{Histopathologic evaluation}

Liver tissue samples were fixed in 10\% formalin buffer, embedded in paraffin, sectioned, and stained with hematoxylin and eosin (H-E) and Perls' Prussian blue. Since a validated histological score for ALD does not yet exist, the non-alcoholic steatohepatitis (NASH) scoring method was adapted ${ }^{(19)}$. Briefly, a semi-quantitative evaluation was performed for the following parameters: steatosis (absent, light, moderate, severe); necroinflammatory activity (absent, light, moderate, severe); fibrosis (absent, periportal or perisinusoidal, periportal and perisinusoidal, bridging fibrosis, cirrhosis); and iron stores grade (with Perls coloration and evaluation with Scheuer's scale). "Significant liver iron stores" were defined as Perls grade 2 or higher. "Significant fibrosis" was assigned according to the presence of periportal and perisinusoidal, bridging fibrosis, or cirrhosis. Necroinflammatory activity was generally categorized as absent or present, regardless of grade. Any amount of alcohol ingested on a daily basis led to categorization as "active alcoholism".

\section{Biochemical and imaging evaluations}

Cases and controls underwent routine laboratory testing for markers of liver disease, inflammation, and kidney function. Specifically, measurements were taken of complete blood count, international normalized ratio (INR), glucose, ALT, AST, GGT, ALP, CRP, ceruloplasmin, al-antitripsin, serum iron, serum ferritin, and serum transferrin saturation. In addition, serological markers for hepatitis B virus (HBV) and hepatitis $\mathrm{C}$ virus (HCV) infections were assayed.

All study participants had undergone a previous liver ultrasound evaluation and the scan images were collected for assessment.

Blood samples were collected from all study participants and used for $H F E$ genotyping with the Haemochromatosis StripAssay A (Vienna Lab, Vienna, Austria) according to the manufacturer's protocol. This test detects some of the very rare HFE mutations (E168Q, E168X, V59M, H63H, P160delC, Q127H, Q283P, V53M, and W164X) as well as mutations in the ferroportin 1 gene and the transferrin receptor type 2 gene.

\section{Statistical analysis}

All statistical analyses were carried out with the SPSS Statistics Data Editor 20 software (IBM; http://www-01.ibm. $\mathrm{com} /$ software/analytics/spss/). Groups were characterized using descriptive statistics, means, standard deviation, and percentages. Categorical variables were analysed by the Chisquared $\left(\chi^{2}\right)$ test, with Yates continuity correction or Fisher's exact test as appropriate. Paired parametric numerical 
variables were analysed for normal distribution by using the Shapiro-Wilk test; then, the difference between two sample means was assessed for statistical significance by using the Student's $t$-test or the non-parametrical Mann-Whitney U test for non-normally distributed variables.

Multivariate logistic regression analysis was carried out to calculate odds ratios (OR) for the presence of at least one $H F E$ mutation using the following covariates: age, sex, body mass index (BMI), active alcoholism, model for end-stage liver disease (MELD), haemoglobin, CRP, serum ferritin, and transferrin saturation. OR and $95 \%$ confidence intervals (CI) were determined for the following outcomes: significant liver iron stores vs no significant liver iron stores; necroinflammatory activity vs no necroinflammatory activity; and significant fibrosis vs no significant fibrosis. The same model, without the covariates serum ferritin and transferrin saturation, was used to evaluate abnormal serum ferritin $(>322 \mathrm{ng} / \mathrm{mL})$ vs normal serum ferritin.

Correlations between variables were evaluated with Spearman's correlation coefficient. All $P$-values were two-sided and $P<0.05$ was considered statistically significant.

\section{RESULTS}

Table 1 presents the clinical and laboratory characteristics of ALD patients and healthy controls. The average age was similar between the two groups; however, the ALD patients had a significantly higher proportion of men. The majority of ALD patients had significant fibrosis, as evidenced by histological grading of liver samples. In addition, $41.3 \%$ of ALD patients were cirrhotic.
The ALD patients showed significantly higher levels of creatinine, but for both groups the levels were within normal range (considering standard deviations). Serum ferritin levels and transferrin saturation were also significantly higher in ALD patients than in controls. No significant differences were observed between the two groups for hemoglobin values, white blood cell count, or CRP.

Genotyping detected only three HFE mutations (C282Y, $\mathrm{H} 63 \mathrm{D}$ and $\mathrm{S} 65 \mathrm{C}$ ) among all the ALD patients and controls. In addition, neither the ferroportin 1 mutation nor the transferrin receptors type 2 mutation was detected in any of the study samples. None of the ALD patients (or controls) were diagnosed as hereditary hemochromatosis (C282Y/C282Y) upon genotyping. There were no significant differences in genotype frequencies observed between the ALD patients and controls (Table 2). Heterozygous $\mathrm{C} 282 \mathrm{Y}$ and compound heterozygous $\mathrm{C} 282 \mathrm{Y} / \mathrm{H} 63 \mathrm{D}$ were detected only in ALD patients, and the prevalence of wild-type (WT) genotypes was slightly lower in the ALD patients; however, neither of

TABLE 2. HFE genotype frequencies*

\begin{tabular}{lccc}
\hline & ALD $(\mathbf{n}=63)$ & Controls $(\mathbf{n}=52)$ & $P$ \\
\hline WT/WT & 61.9 & 65.4 & NS \\
WT/C282Y & 1.6 & 0 & NS \\
C282Y/H63D & 3.2 & 0 & NS \\
WT/H63D & 27.0 & 26.9 & NS \\
H63D/H63D & 3.2 & 1.9 & NS \\
WT/S65C & 1.6 & 5.8 & NS \\
H63D/S65C & 1.6 & 0 & NS \\
At least one HFE mutation & 38.1 & 32.7 & NS \\
\hline
\end{tabular}

* Data are presented as percent

TABLE 1. Clinical and laboratory characteristics of ALD patients and healthy controls

\begin{tabular}{|c|c|c|c|}
\hline & $\operatorname{ALD}(n=63)$ & Controls $(n=52)$ & $P$ \\
\hline Age, years & $53.17 \pm 10.74$ & $48.35 \pm 15.38$ & NS \\
\hline Males, $\%$ & 84.1 & 28.8 & $<0.0001$ \\
\hline Active alcoholism, $\%$ & 61.9 & - & - \\
\hline Daily consumption, $g$ & $164.76 \pm 55.37$ & - & - \\
\hline Lifetime total consumption, $\mathrm{kg}$ & $2227.63 \pm 1044.30$ & - & - \\
\hline Significant fibrosis*, $\%$ & 65.1 & - & - \\
\hline Cirrhosis, $\%$ & 41.3 & - & - \\
\hline MELD & $7.63 \pm 4.55$ & - & - \\
\hline WBC, $\times 10^{9} / \mathrm{L}$ & $6.02 \pm 2.08$ & $6.35 \pm 1.66$ & NS \\
\hline Hemoglobin, g/L & $13.47 \pm 1.12$ & $13.92 \pm 1.12$ & NS \\
\hline Creatinine, $\mathrm{mg} / \mathrm{dL}$ & $0.89 \pm 0.27$ & $0.79 \pm 0.15$ & 0.036 \\
\hline Serum iron, $\mu \mathrm{g} / \mathrm{dL}$ & $115.59 \pm 58.38$ & $97.10 \pm 37.10$ & NS \\
\hline Serum ferritin, $\mathrm{ng} / \mathrm{mL}$ & $450.24 \pm 404,62$ & $160.64 \pm 131.23$ & $<0.0001$ \\
\hline Transferrin saturation, $\%$ & $39.40 \pm 19.91$ & $30.12 \pm 11.78$ & 0.035 \\
\hline $\mathrm{CRP}, \mathrm{mg} / \mathrm{dL}$ & $0.96 \pm 1.55$ & $0.50 \pm 0.65$ & NS \\
\hline
\end{tabular}

*perisinusoidal and portal/periportal fibrosis, bridging fibrosis, or cirrhosis 
TABLE 3. Comparison between ALD patients with and without any HFE mutation

\begin{tabular}{|c|c|c|c|}
\hline & At least one HFE mutation $(n=24)$ & WT/WT HFE $(\mathrm{n}=39)$ & $P$ \\
\hline Age, years & $52.04 \pm 10.81$ & $53.87 \pm 10.80$ & NS \\
\hline Males, $\%$ & 79.2 & 87.2 & NS \\
\hline BMI & $26.62 \pm 3.04$ & $26.75 \pm 3.44$ & NS \\
\hline Active alcoholism, $\%$ & 54.2 & 66.7 & NS \\
\hline Daily consumption, $g$ & $172.0 \pm 50,64$ & $160.31 \pm 58.28$ & NS \\
\hline Lifetime total consumption, $\mathrm{kg}$ & $2277.58 \pm 1127.48$ & $2196.90 \pm 1003.84$ & NS \\
\hline Significant fibrosis*, $\%$ & 58.3 & 69.2 & NS \\
\hline Necroinflammatory activity, $\%$ & 20.8 & 30.8 & NS \\
\hline Significant iron liver stores $* *, \%$ & 37.5 & 12.8 & 0.031 \\
\hline Serum iron, $\mu \mathrm{g} / \mathrm{dL}$ & $118.54 \pm 57.98$ & $113.80 \pm 59.30$ & NS \\
\hline Serum ferritin, $\mathrm{ng} / \mathrm{mL}$ & $512.25 \pm 469.47$ & $412.08 \pm 360.26$ & NS \\
\hline Transferrin saturation, $\%$ & $41.12 \pm 22.33$ & $38.35 \pm 18.50$ & NS \\
\hline MELD & $7.13 \pm 4.36$ & $7.95 \pm 4.69$ & NS \\
\hline WBC, $\times 10^{9} / \mathrm{L}$ & $6.18 \pm 2.08$ & $5.92 \pm 2.07$ & NS \\
\hline Neutrophils, x109/L & $3.88 \pm 1.79$ & $3.73 \pm 1.62$ & NS \\
\hline Lymphocytes, x109/L & $1.55 \pm 0.54$ & $1.50 \pm 0.56$ & NS \\
\hline Haemoglobin, g/L & $13.86 \pm 1.99$ & $13.23 \pm 1.98$ & NS \\
\hline Platelets, x109/L & $148.71 \pm 74.24$ & $152.36 \pm 94.69$ & NS \\
\hline $\mathrm{MCV}, \mathrm{fL}$ & $98.60 \pm 7.49$ & $96.74 \pm 6.25$ & NS \\
\hline INR & $1.15 \pm 0.20$ & $1.22 \pm 0.25$ & NS \\
\hline Albumin, $g / d L$ & $3.95 \pm 0.58$ & $3.61 \pm 0.89$ & NS \\
\hline Alkaline phosphatase, UI/L & $104.89 \pm 45.99$ & $128.74 \pm 70.01$ & NS \\
\hline GGT, UI/L & $172.15 \pm 164.81$ & $252.57 \pm 271.38$ & NS \\
\hline ALT, UI/L & $38.75 \pm 14,65$ & $44.13 \pm 35.99$ & NS \\
\hline AST, UI/L & $58.83 \pm 46.26$ & $60.05 \pm 33.38$ & NS \\
\hline Total bilirubin, $\mathrm{mg} / \mathrm{dL}$ & $1.96 \pm 3.81$ & $1.58 \pm 1.28$ & NS \\
\hline Creatinine, $\mathrm{mg} / \mathrm{dL}$ & $0.90 \pm 0.23$ & $0.89 \pm 0.3$ & NS \\
\hline $\mathrm{CRP}, \mathrm{mg} / \mathrm{dL}$ & $1.25 \pm 2.31$ & $0.78 \pm 0.80$ & NS \\
\hline
\end{tabular}

*perisinusoidal and portal/periportal fibrosis, bridging fibrosis or cirrhosis

**Iron stores Perls grade 2 or higher

these differences reached statistical significance. The most frequently detected non-WT genotype, heterozygous H63D, was identically distributed between the two groups. The $\mathrm{S} 65 \mathrm{C}$ mutations were slightly more prevalent in the controls.

Table 3 presents the distribution of ALD patients with at least one HFE mutation in comparison to those with WT genotypes. Correlation analysis indicated that the ALD patients with at least one $H F E$ mutation had significantly higher liver iron stores (Perls grade 2 or higher) than those with WT genotypes. There was also a trend toward higher serum ferritin values in the ALD patients with at least one HFE mutation. All other variables were similar between the two subgroups.

Multivariate logistic regression analysis of the ALD patients having at least one $H F E$ mutation with adjustments for age, sex, BMI, active alcoholism, MELD, haemoglobin, CRP, serum ferritin and transferrin saturation indicated that the OR for significant liver iron stores was 17.23 (95\% CI: $2.09-142.34, P=0.008)$. In contrast, the analysis indicated no significantly increased risk associated with significant fibrosis $(\mathrm{OR}=0.60,95 \% \mathrm{CI}: 0.14-2.67)$ or necroinflammatory activity $(\mathrm{OR}=0.42,95 \%$ CI: 0.07-2.68) (Figure 1$)$.

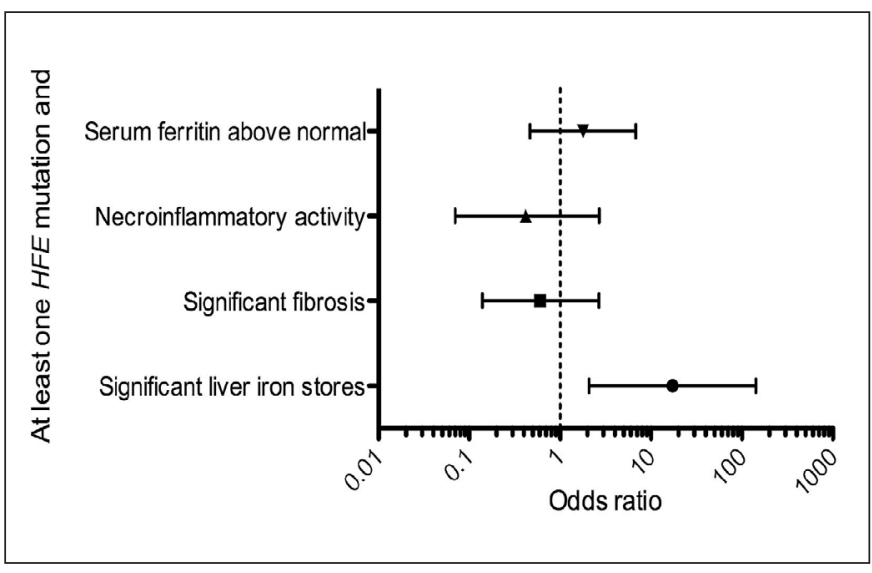

FIGURE 1. Odds ratios for having at least one HFE mutation and ALD-related complications

The strongest determinant factor for having a serum ferritin higher than normal was the presence of active alcoholism $(\mathrm{OR}=8.87,95 \% \mathrm{CI}: 2.11-34.78, P=0.003)$. The presence of 
at least one HFE mutation (when adjusted for age, sex, BMI, active alcoholism, MELD, haemoglobin, and CRP) did not significantly increase the risk of having an increased serum ferritin level (OR $=1.79,95 \%$ CI: 0.47-6.79) (Figure 2).

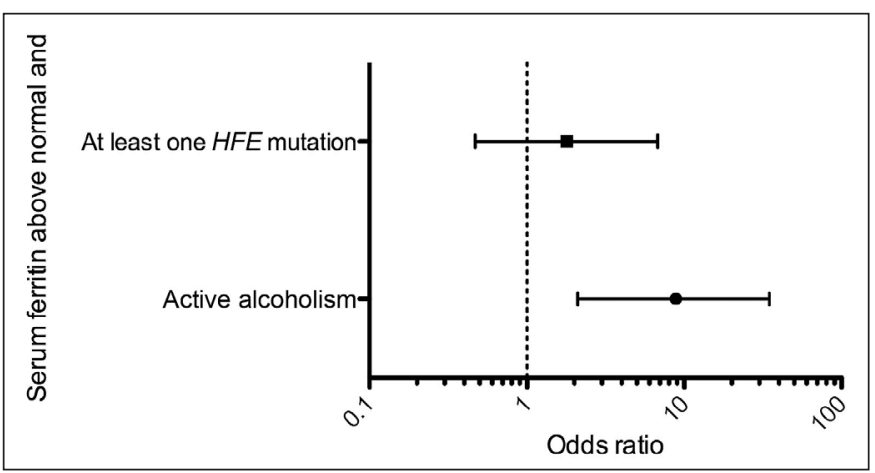

FIGURE 2. Odds ratios for having serum ferritin above normal and active alcoholism or at least one HFE mutation

Correlation analysis indicated that the serum ferritin level in ALD patients was significantly associated with Perls grade $\left(r_{s}=0.542, P<0.0001\right)$, GGT levels $\left(r_{s}=0.374, P=0.003\right)$, and ALT $\left(\mathrm{r}_{\mathrm{s}}=0.265 P=0.036\right)$, but not with AST, steatosis, or fibrosis grades.

The variables showing the strongest associations with fibrosis grade were the amount of daily alcohol consumption $\left(r_{s}=0.308, P=0.014\right)$ and lifetime total alcohol consumption $\left(\mathrm{r}_{\mathrm{s}}^{\mathrm{s}}=0.302, P=0.016\right)$.

\section{DISCUSSION}

Our study population mirrored the known impact of alcoholism in our country, wherein most ALD patients are young/middle aged (mean: 53 years old) males with high daily alcohol intake, in many cases since childhood. In addition, these patients often present with advanced fibrosis grades. Meanwhile, the control group reflected the common trend of more women having gallstones than men. Unfortunately, these distinguishing features of the two groups may have induced a bias in our comparison of serum iron, ferritin, and transferrin saturation. We attempted to reduce the effects of this bias as much as possible by excluding all controls with hemoglobin and serum ferritin below normal or with biochemical evidence of inflammation. However, it is important to note that the purpose of this study was not to demonstrate that ALD patients have iron overload, as this fact is already sufficiently well established in the literature. Since HFE mutations are not sex-linked, it is unnecessary to match groups of ALD patients and healthy controls for sex when studying the prevalence of these mutations between the two groups.

In the current study, we did not find evidence that $H F E$ mutations are more frequent in ALD patients; therefore, the iron overload that was present in this group must be explained by some other factor. We recently identified inappropriately low liver hepcidin mRNA expression in alcoholic patients as a potential cause of ALD iron overload, and this may be one such factor ${ }^{(5)}$.

Comparison between the ALD patient subgroups - with and without HFE mutations - provided more interesting results. The subgroups were similar for age, percentage of males, BMI, percentage of active alcoholism, and amounts of alcohol ingested. We found that the presence of at least one HFE mutation increased the risk of higher liver iron stores, but no evidence to suggest that it may have influence on the disease severity; specifically, these carriers were not at an increased risk for significant fibrosis or necroinflammatory activity in their liver tissues. The fact that having at least one HFE mutation did not increase the risk of having ferritin above normal, despite active alcohol intake, is intriguing and future studies should assess the potentially different impact of $H F E$ mutations on systemic and liver iron stores.

Our study's findings also confirmed that the most relevant factor for ALD progression to cirrhosis is the lifetime amount of alcohol consumed.

As serum ferritin levels showed a strong association with the liver biopsy Perls grade, we believe that this measurement represents a simple, cheap, effective, non-invasive marker for estimating the severity of liver iron stores in ALD patients.

Two previous studies have demonstrated correlation between HFE mutations and iron overload/ALD progres$\operatorname{sion}^{(3,33)}$. In a Spanish population with advanced ALD, H63D mutations were more frequent than in the general population $(\mathrm{OR}=1.66,95 \% \mathrm{CI}: 1.10-2.52, P=0.01)$ and no association was found with $\mathrm{C} 282 \mathrm{Y}$ in $\operatorname{particular}^{(30)}$. Another study from Portugal found a correlation with the H63D mutation and liver disease in alcoholics who consumed $>80 \mathrm{~g} /$ day $(\mathrm{OR}=1.57,95 \% \mathrm{CI}: 1.02-2.40$, $P=0.02)^{(23)}$. However, all other related studies have found no evidence of correlation for the HFE mutations and the risk of developing ALD. For example, one British study from Newcastle ${ }^{(15)}$, involving 257 ALD patients and 117 controls, did not show any association between HFE mutations and iron liver stores or advanced fibrosis. Another, from Sheffield ${ }^{(14)}$, also failed to demonstrate any difference between the frequencies of $H F E$ mutations between two alcoholic groups, one with established cirrhosis and another without liver disease.

In general, studies from Caucasian populations, mainly in Europe, have shown that HFE mutations are not associated with alcohol-related liver disorders. A study from Spain found no differences in the distribution of $\mathrm{C} 282 \mathrm{Y}$ or H63D mutations between alcoholic cirrhosis patients, $\mathrm{HCV}$ cirrhosis patients, and healthy controls. However, C282Y heterozygosity was much more frequent $(20.9 \%)$ in a subgroup of the alcoholic cirrhosis patients with hepatocellular carcinoma (vs those without tumour) ${ }^{(21)}$. Similarly, a study from Switzerland found no association with $\mathrm{C} 282 \mathrm{Y}$ heterozygosity and alcoholic cirrhosis ${ }^{(12)}$. Yet another study from New Zealand ${ }^{(29)}$, using patients in an inpatient alcohol addiction clinic, found no differences the frequencies of $H F E$ mutations compared to the general population and no as- 
sociation of these mutations with liver function or liver iron stores. Similar reports came from Australia ${ }^{(26)}$ and Poland ${ }^{(28)}$.

Our data agrees with the majority of previously published studies showing no differences in the distributions of $H F E$ mutations among ALD patients and healthy controls. Likewise, the evidence that these mutations are not associated with an increased risk of severe fibrosis or impaired liver function are concordant. The novelty of our work, however, lies in our demonstration that the presence of at least one HFE mutation in ALD patients is significantly associated with higher liver iron stores. This is an interesting finding, as tissue iron overload is thought to be relevant to fibrosis and inflammation but neither of these features were strongly associated in our ALD patient group.

The collective findings from our study indicate that $H F E$ mutations may play a minor role in the ALD feature of increased liver iron stores while not conferring increased risk for fibrosis grade or disease activity.

\section{ACKNOWLEDGEMENTS}

We are grateful to the Centro Hospitalar Tondela-Viseu E.P.E. for funding this research.

Costa-Matos L, Batista P, Monteiro N, Henriques P, Girão F, Carvalho A. Mutações HFE e sobrecarga de ferro em pacientes com doença hepática alcoólica. Arq Gastroenterol. 2013;50(1):35-41

RESUMO - Contexto - A doença hepática alcoólica (DHA) está geralmente associada à sobrecarga de ferro, que pode contribuir para a sua patogênese, através do aumento do estresse oxidativo e dano celular. As descrições existentes na literatura sobre a associação entre mutações $H F E$ e a gravidade da DHA nem sempre são concordantes. Objetivos - Comparar a prevalência de mutações HFE entre um grupo de pacientes com DHA e uma população de controle. Avaliar a relação entre mutações $H F E$ e os depósitos de ferro hepático. Avaliar se a presença dessas mutações está associada com a gravidade da DHA. Métodos - Compararam-se 63 pacientes com DHA que efetuaram biopsia hepática com 52 controles saudáveis. A genotipagem HFE (wild type, C282Y, H63D, S65C, E168Q, E168X, V59M, H63H, P160delC, Q127H, Q283P, V53M, W164X) e uma avaliação laboratorial de rotina (incluindo cinética do ferro) foram feitos em todos os indivíduos. Realizou-se regressão logística multivariada nos casos para avaliar se a presença de mutações HFE estava relacionada com risco aumentado de depósitos de ferro hepático aumentados, ferritina sérica anormal, fibrose hepática significativa ou atividade necroinflamatória. Resultados - Os pacientes apresentaram ferritina sérica e saturação da transferrina mais elevadas que os controles, mas não existiram diferenças significativas na distribuição de mutações $H F E$ entre pacientes e controles. Considerando apenas os pacientes, o risco relativo de estes apresentarem pelo menos uma mutação HFE e depósitos de ferro hepático significativos foi de 17.23 (CI 95\% 2.09-142.34, $P=0.008)$. Contudo, a presença de pelo menos uma mutação $H F E$ não esteve associada ao risco significativamente aumentado de fibrose ou atividade necroinflamatória significativas. $\mathrm{O}$ fator mais determinante para apresentar ferritina sérica acima do normal foi a presença de alcoolismo ativo, com risco relativo de 8.87 (CI 95\% 2.11-34.78, $P$ = 0.003). Conclusões - Não existiram diferenças na distribuição de mutações $H F E$ entre pacientes com DHA e controles normais. Nos pacientes, o achado de pelo menos uma mutação HFE aumentou o risco de ter depósitos de ferro hepático mais elevados, mas não para ter fibrose ou atividade necroinflamatória significativas.

DESCRITORES - Hepatopatias alcoólicas. Proteínas de membrana. Ferro. Hemocromatose. 


\section{REFERENCES}

1. Aranda N, Viteri FE, Montserrat C, Arija V. Effects of C282Y, H63D, and S65C HFE gene mutations, diet, and life-style factors on iron status in a general Mediterranean population from Tarragona, Spain. Ann Hematol. 2010;89:767-73.

2. Bell H, Skinningsrud A, Raknerud N, Try K. Serum ferritin and transferrin saturation in patients with chronic alcoholic and non-alcoholic liver diseases. $\mathrm{J}$ Intern Med. 1994;236:315-22.

3. Bonkovsky HL, Lambrecht RW, Shan Y. Iron as a co-morbid factor in nonhemochromatotic liver disease. Alcohol. 2003;30:137-44.

4. Bulaj ZJ, Griffen LM, Jorde LB, Edwards CQ, Kushner JP. Clinical and biochemical abnormalities in people heterozygous for hemochromatosis. N Engl J Med. 1996;335:1799-805.

5. Costa-Matos L, Batista P, Monteiro N, Simões M, Egas C, Pereira J, Pinho H, Santos N, Ribeiro J, Cipriano MA, Henriques P, Girão F, Rodrigues A, Carvalho A. Liver hepcidin mRNA expression is inappropriately low in alcoholic patients compared with healthy controls. Eur J Gastroenterol Hepatol. 2012;24:1158-65.

6. European Association for the Study of the Liver. EASL clinical practice guidelines for HFE hemochromatosis. J Hepatol. 2010;53:3-22. [PMID: 20471131].

7. Feder JN, Gnirke A, Thomas W, Tsuchihashi Z, Ruddy DA, Basava A, Dormishian F, Domingo R Jr., Ellis MC, Fullan A, Hinton LM, Jones NL, Kimmel BE, Kronmal GS, Lauer P, Lee VK, Loeb DB, Mapa FA, McClelland E, Meyer NC, Mintier GA, Moeller N, Moore T, Morikang E, Prass CE, Quintana L, Starnes SM, Schatzman RC, Brunke KJ, Drayna DT, Risch NJ, Bacon BR, Wolff RK. A novel MHC class I-like gene is mutated in patients with hereditary haemochromatosis. Nat Genet. 1996;13:399-408. [PMID: 8696333].

8. Fletcher LM, Halliday JW, Powell LW. Interrelationships of alcohol and iron in liver disease with particular reference to the iron-binding proteins, ferritin and transferrin. J Gastroenterol Hepatol. 1999;14:202-14.

9. Fletcher LM, Dixon JL, Purdie DM, Powell LW, Crawford DH. Excess alcoho greatly increases the prevalence of cirrhosis in hereditary hemochromatosis. Gastroenterology. 2002;122:281-9.

10. Fletcher LM, Bridle KR, Crawford DH. Effect of alcohol on iron storage diseases of the liver. Best Pract Res Clin Gastroenterol. 2003;17:663-77.

11. Fletcher LM, Powell LW. Hemochromatosis and alcoholic liver disease. Alcohol. 2003;30:131-6

12. Frenzer A, Rudzki Z, Norton ID, Butler WJ, Roberts-Thomson IC. Heterozygosity of the haemochromatosis mutation, C282Y, does not influence susceptibility to alcoholic cirrhosis. Scand J Gastroenterol. 1998;33:1324.

13. Ganne-Carrié N, Christidis C, Chastang C, Ziol M, Chapel F, Imbert-Bismut F, Trinchet JC, Guettier C, Beaugrand M. Liver iron is predictive of death in alcoholic cirrhosis: a multivariate study of 229 consecutive patients with alcoholic and/ or hepatitis C virus cirrhosis: a prospective follow up study. Gut. 2000;46:277-82.

14. Gleeson D, Evans S, Bradley M, Jones J, Peck RJ, Dube A, Rigby E, Dalton A. HFE genotypes in decompensated alcoholic liver disease: phenotypic expression and comparison with heavy drinking and with normal controls. Am J Gastroenterol. 2006;101:304-10.

15. Grove J, Daly AK, Burt AD, Guzail M, James OF, Bassendine MF, Day CP. Heterozygotes for HFE mutations have no increased risk of advanced alcoholic liver disease. Gut. 1998;43:262-6.

16. Hanson EH, Imperatore G, Burke W. HFE gene and hereditary hemochromatosis: a HuGE review. Human genome epidemiology. Am J Epidemiol. 2001;154:193206.

17. Hearnshaw S, Thompson NP, McGill A. The epidemiology of hyperferritinaemia World J Gastroenterol. 2006;12:5866-9.
18. Ioannou GN, Dominitz JA, Weiss NS, Heagerty PJ, Kowdley KV. The effect of alcohol consumption on the prevalence of iron overload, iron deficiency, and iron deficiency anemia. Gastroenterology. 2004;126:1293-301.

19. Kleiner DE, Brunt EM, Van Natta M, Behling C, Contos MJ, Cummings OW, Ferrell LD, Liu YC, Torbenson MS, Unalp-Arida A, Yeh M, McCullough AJ, Sanyal AJ; Nonalcoholic Steatohepatitis Clinical Research Network. Design and validation of a histologic scoring system for nonalcoholic fatty liver disease. Hepatology 2005;41:1313-21.

20. Kohgo Y, Ohtake T, Ikuta K, Suzuki Y, Hosoki Y, Saito H, Kato J. Iron accumulation in alcoholic liver diseases. Alcohol Clin Exp Res. 2005;29:189s-93s.

21. Lauret E, Rodríguez M, González S, Linares A, López-Vázquez A, Martínez-Borra J, Rodrigo L, López-Larrea C. HFE gene mutations in alcoholic and virus-related cirrhotic patients with hepatocellular carcinoma. Am J Gastroenterol. 2002;97:1016-21

22. Lim EM, Rossi E, De Boer WB, Reed WD, Jeffrey GP. Hepatic iron loading in patients with compound heterozygous HFE mutations. Liver Int. 2004;24:631-6.

23. Machado MV, Gonçalves MS, Cortez-Pinto H. Metabolismo do ferro em alcoólicos crónicos em consumo activo e durante a abstinência. J Port Gastrenterol. 2004:11:186-90.

24. Machado MV, Ravasco P, Martins A, Almeida MR, Camilo ME, Cortez-Pinto H. Iron homeostasis and H63D mutations in alcoholics with and without live disease. World J Gastroenterol. 2009;15:106-11.

25. Milman N, Ovesen L, Byg K, Graudal N. Iron status in Danes updated 1994 I: prevalence of iron deficiency and iron overload in 1332 men aged 40-70 years. Influence of blood donation, alcohol intake, and iron supplementation. Ann Hematol. 1999;78:393-400.

26. Olynyk JK, Knuiman MW, Divitini ML, Bartholomew HC, Cullen DJ, Powel LW. Effects of HFE gene mutations and alcohol on iron status, liver biochemistry and morbidity. J Gastroenterol Hepatol. 2005;20:1435-41.

27. Pascoe A, Kerlin P, Steadman C, Clouston A, Jones D, Powell L, Jazwinska E, Lynch S, Strong R. Spur cell anaemia and hepatic iron stores in patients with alcoholic liver disease undergoing orthotopic liver transplantation. Gut. 1999;45:301-5.

28. Raszeja-Wyszomirska J, Kurzawski G, Zawada I, Suchy J, Lubinski J, Milkiewicz P. HFE gene mutations in patients with alcoholic liver disease. A prospective study from northwestern Poland. Pol Arch Med Wewn. 2010;120:127-31.

29. Robinson G, Narasimhan S, Weatherall M, Beasley R. Hemochromatosis gene mutations, liver function tests and iron status in alcohol-dependent patients admitted for detoxification. J Gastroenterol Hepatol. 2007;22:852-4.

30. Ropero Gradilla P, Villegas Martínez A, Fernández Arquero M, García-Agúndez JA, González Fernández FA, Benítez Rodríguez J, Díaz-Rubio M, de la Concha EG, Ladero Quesada JM. C282Y and H63D mutations of HFE gene in patients with advanced alcoholic liver disease. Rev Esp Enferm Dig. 2001;93:156-63.

31. Scotet V, Mérour MC, Mercier AY, Chanu B, Le Faou T, Raguénes O, Le Gac G, Mura C, Nousbaum JB, Férec C. Hereditary hemochromatosis: effect of excessive alcohol consumption on disease expression in patients homozygous for the $\mathrm{C} 282 \mathrm{Y}$ mutation. Am J Epidemiol. 2003;158:129-34.

32. Sebastiani G, Walker AP. HFE gene in primary and secondary hepatic iron overload. World J Gastroenterol. 2007;13:4673-89.

33. Wallace DF, Subramaniam VN. Co-factors in liver disease: the role of HFE-related hereditary hemochromatosis and iron. Biochim Biophys Acta. 2009;1790:663-70.

34. Whitfield JB, Zhu G, Heath AC, Powell And LW, Martin NG. Effects of alcohol consumption on indices of iron stores and of iron stores on alcohol intake markers. Alcohol Clin Exp Res. 2001;25:1037-45. 